Hana Komlenac

Zagreb

hanakomlenac@gmail.com
DOI 10.32458/ei.25.5

UDK 069.42(497.521.2):39 005.92:069](497.521.2)

Stručni rad

Primljeno: 20. svibnja 2020.

Prihvaćeno: 18. lipnja 2020.

\title{
Hemeroteka Etnografskoga muzeja u Zagrebu
}

Rad donosi prikaz procesa sistematizacije i digitalizacije hemerotečne građe u Etnografskom muzeju s naglasakom na shvaćanje pojma hemeroteke tijekom sto godina djelovanja Muzeja. U uvodnom je dijelu predstavljena hemeroteka unutar teorijskih i zakonodavnih okvira na temelju koje je započet rad tijekom 2019. godine. Nadalje, tekst donosi spoznaje koje su prethodile današnjem stanju hemeroteke što uključuje analizu građe, odnosno politike skupljanja hemerotečne građe. Osim dosadašnjega procesa digitalizacije i obrade građe u fondu Hemeroteke, rad se bavi i suvremenim praksama.

Ključne riječi: Etnografski muzej (Zagreb)

dokumentacija, hemeroteka, povijest muzeja

\section{UVOD}

U dokumentaciji Etnografskoga muzeja od početka njegova djelovanja prikupljana je građa koja se odnosila na muzejske predmete, djelovanje Muzeja i stručni rad djelatnika te na hemerotečnu građu. U ovom tekstu bit će prikazana struktura i razvoj hemeroteke tijekom sto godina djelovanja Etnografskoga muzeja. U istraživanju je korištena literatura koja se odnosi na povijest, organizaciju i djelovanje Muzeja, trenutno važeće zakone i pravilnike te literatura koja se odnosi na muzejsku dokumentaciju. ${ }^{1}$

Cilj teksta je prikazati povijesni pregled formiranja fonda Hemeroteke u Etnografskom muzeju, predstaviti (vlastiti) rad na hemeroteci i planove u vezi daljnje obrade.

1 Hemeroteka Etnografskoga muzeja u Zagrebu bila mi je tema pismenoga dijela stručnoga ispita za zvanje kustos 2020. godine. 
U uvodnom dijelu teksta napravljen je kraći osvrt na pojam muzejske dokumentacije i hemeroteke unutar teorijskih i zakonodavnih okvira kako bi se prikazalo da je muzejska dokumentacija relativno kasno definirana zakonima, kao i hemeroteka. Zatim slijedi poglavlje u kojem je predstavljena povijest muzejske dokumentacije i dokumentacijskih fondova Etnografskoga muzeja u Zagrebu.

U sljedećem poglavlju će se predstaviti stanje fonda Hemeroteke koje je prethodilo obradi te analiza građe. Zaključno poglavlje donosi prikaz dosadašnjega procesa digitalizacije i obrade građe $u$ fondu Hemeroteke te analizu digitalizirane građe.

\section{HEMEROTEKA I MUZEJSKA DOKUMENTACIJA KROZ TEORIJU I ZAKONSKE OKVIRE}

Teorijske postavke u muzeologiji o načinima vođenja muzejske dokumentacije bazirane na znanstvenom radu povjesničara umjetnosti i muzeologa Ive Maroevića predstavljam u odnosu s važećim zakonskim regulativama i praksama u svakodnevim situacijama. Prema Ivi Maroeviću muzejska dokumentacija je "proces bilježenja podataka i informacija koje smo tijekom istraživanja, promatranja ili tumačenja muzejskog predmeta prenijeli na neki drugi medij, kako bismo se njima mogli služiti kao određenim znanjem o predmetu. To je svojevrsni oblik materijaliziranja informacija s ciljem njihova očuvanja i mogućnosti prijenosa posredstvom drugih medija. Svrha dokumentacije je postići što vjerniju predodžbu o predmetu o kojem je riječ, sa svih aspekata ljudskih interesa." (Maroević 1993: 190)

Tijekom godina, kroz zakonsku regulativu, mijenjala se važnost, opseg i način obrade dokumentacije. Prvi propis ${ }^{2}$ koji pobliže definira sadržaj, oblike i načine vođenja muzejske dokumentacije je "Pravilnik o sadržaju i načinu vođenja muzejske dokumentacije o muzejskoj građi” (NN 108/2002). Taj Pravilnik dokumentaciju dijeli na primarnu, sekundarnu i tercijarnu te je definira kao "sustavno izrađen, prikupljen, organiziran i pohranjen skup podataka, koji je nastao u tijeku procesa stručne obrade, zaštite i prezentacije muzejske građe, te se temelji na dogovorenom i utvrđenom broju i kvaliteti podataka o predmetu, grupi predmeta ili cjelokupnom fondu. Muzejska dokumentacija se stvara u postupcima inventarizacije, katalogiziranja i indeksiranja, koji predstavljaju trajan proces obrade i nadopunjavanja podataka." (NN 108/2002, čl. 2)

"Svrha je vođenja muzejske dokumentacije da se preko pregledno i sustavno obrađenih fondova pruži točna informacija o muzejskoj građi, njezinu stanju, izložbama, drugim manifestacijama i aktivnostima muzeja, te o povijesti muzeja sa stručnog i znanstvenog aspekta." (NN 108/2002, čl. 3)

Hemeroteka (grč. ij̣ $\mu$ ṕa: dan + -teka) je prema Hrvatskoj enciklopediji: "zbirka novina i časopisa; zbirka izrezaka iz tekućih novina, časopisa ili koje druge tiskane građe, o određenim, unaprijed utvrđenim temama ili predmetima, obično složena prema abecednom ili kronološkom slijedu natuknica. Koristi se u knjižnicama ili drugim

2 Smjernice o dokumentiranju muzejskih i galerijskih predmete donesene su 1987. godine u časopisu "Muzeologija" br. 25. 
informacijskim ustanovama kao brz izvor informacija i za dopunu podataka, osobito o aktualnim temama i događajima." ${ }^{3}$

Maroević dijeli dokumentaciju prema sadržaju i funkciji te razlikuje tri grupe: primarnu, sekundarnu i tercijarnu dokumentaciju. Primarna dokumentacija nastaje u neposrednom dodiru s predmetima, a podaci o njima nastaju "istraživanjem, zaštitom i komuniciranjem predmeta baštine, pokrivaju njihovo poznavanje i sve vrste zbivanja u njima i oko njih ili zbivanja u kojima je predmet subjekt ili objekt." (Maroević 1993: 191-192) U primarnu dokumentaciju prema istom autoru svrstavaju se i dokumentacijske zbirke poput hemeroteke. ${ }^{4}$

Prije donošenja "Pravilnika o sadržaju i načinu vođenja muzejske dokumentacije o muzejskoj građi” 2002. godine, hemeroteka je u muzejskoj struci shvaćana šire. ${ }^{5}$ Primjer tomu je i Etnografski muzej u Zagrebu gdje su se uz hemeroteku prikupljali plakati i čuvali u knjižnici. Prema Pravilniku hemeroteka sadrži članke iz novina i časopisa o muzejskom fundusu, izložbama, drugim programskim aktivnostima i povijesti ustanove te stručnom osoblju (NN 108/2002, čl. 27). Ona spada u sekundarnu dokumentaciju te je obrada ovoga fonda zakonska obveza.

S obzirom na razvoj tehnologije i pojavu novih medija, novi pravilnik o dokumentaciji u pripremi, koji prati Zakon o muzejima iz 2018., trebao bi proširiti definiciju i shvaćanje hemerotečne građe. Tako se pojam hemeroteke ne bi odnosio samo na tiskovine već i na sve medijske objave (televizija, radio, internetski portali).

\section{POVIJEST MUZEJSKE DOKUMENTACIJE I DOKUMENTACIJSKIH FONDOVA ETNOGRAFSKOGA MUZEJA}

"Godine 1919. osniva se Etnografski muzej u Zagrebu. Do spomenute se godine etnografska građa prikupljala u Narodnom muzeju, osnovanom u Zagrebu 1846. godine. Na inicijativu Povjereništva za bogoštovlje i nastavu, 1919. godine spajaju se postojeće etnografske zbirke s ovećom zbirkom tekstila Salamona Bergera u samostalni Etnografski odjel hrvatskoga narodnog muzeja - današnji Etnografski muzej u Zagrebu."”

Od osnutka Muzeja vodi se muzejska dokumentacija vezana uz muzejske predmete (inventarna knjiga, knjiga ulaska, knjiga izlaska). Odmah po osnutku uvedeni su i neki dokumentacijski fondovi poput fototeke, negativoteke i dijateke što je rezultat intenzivnoga terenskog istraživanja. "Među značajnijim istraživanjima u prvim godinama djelovanja Muzeja ističe se Pokupska ekspedicija iz 1923. godine. Građa je bila

3 https://www.enciklopedija.hr/Natuknica.aspx?ID = 24926 (pristup 14. veljače 2020.)

4 Sekundarna dokumentacija obuhvaća prijenos primarne dokumentacije u druge medije (mikrofilm, magnetne vrpce, diskete). Tercijarnu čine "pregledi, kartoteke, katalozi, indeksi, popisi i svi drugi oblici pregleda nad dokumentacijom" (Maroević 1993: 192-193).

5 To potvrđuje primjer Muzeja Slavonije koji u hemerotečnu građu svrstava "novine, izreske, plakate i sitni tisak koji su u velikim količinama pristizali u muzej te se razvrstavala po ostalim odjelima." (Vinaj 1998: 62).

6 http://www.emz.hr/O\%20muzeju/Povijest\%20muzeja (pristup 14. veljače 2020.). 
prikupljana u svrhu proučavanja, rekognosciranja terena te istraživanja etnografskih tema uz primjenu fotografskog, filmskoga i fonografskoga snimanja." (Vlatković 2019: 66) Upravo zato je Vladimir Tkalčić, prvi kustos Etnografskoga muzeja, bio svjestan važnosti dokumentacijske građe te navodi da: "Od pomoćnih ustanova muzeja, bez kakovih se moderni muzej ne da zamisliti, dobro je uređen muzejski arhiv, u kojem je pohranjena originalna raznolika rukopisna etnografska građa, fotografije, crteži, pa arhiv negativa i posebni vanevropski arhiv; priručna biblioteka, koju je trebalo od temelja novo osnovati a sada obaseže oko 1500 brojeva; atelieri za crtanje i slikanje, atelieri za fotografiranje s više aparata i sa svim potrebnim napravama; tehničke radionice za različne stolarske, bravarske i ine poslove te za konserviranje muzejskih predmeta." (Tkalčić 1930: 143)

U dokumentaciji Etnografskoga muzeja od početka djelovanja je prikupljana građa koja se odnosila na muzejske predmete, djelovanje muzeja i stručni rad djelatnika kao i različiti dopisi, izvještaji, zapisnici, normativni akti i druga slična građa. Veći dio građe je prikupljan i pohranjen u Dokumentaciji, ali bez detaljnijih popisa, evidencija ili inventarnih knjiga. Iznimku čini audiovizualna građa za koju su vođene inventarne knjige (negativoteka, dijateka, fototeka) uvedene odmah po osnutku Muzeja zahvaljujući V. Tkalčiću.

Treba istaknuti da je uz inventarne knjige muzejske i dokumentacijske građe vođena i kartoteka s kataloškim karticama prema inventarnom broju te vrsti predmeta i lokalitetu (Vlatković 2019: 65-70).

Dokumentacija Etnografskoga muzeja u Zagrebu danas se vodi u skladu s važećim zakonskim propisima, ponajprije sa Zakonom o muzejima (NN 61/2018) i "Pravilnikom o sadržaju i načinu vođenja muzejske dokumentacije o muzejskoj građi” (NN 108/2002).7

\section{HEMEROTEKA ETNOGRAFSKOGA MUZEJA}

Hemeroteka se navodi u "Pravilima Etnografskog muzeja" iz 1961. godine, prvom poznatom aktu muzeja koji propisuje unutrašnje ustrojstvo. U njima se, kao i u "Statutu Etnografskog muzeja u Zagrebu" iz 1966. godine, navodi kako Odjel dokumentacije evidentira materijal u muzeju i izvan muzeja, vodi arhiv i hemeroteku, fototeku, dijateku i filmoteku te fonoteku.

Statuti Etnografskoga muzeja u Zagrebu doneseni 1970. i 1971. godine ne navode vođenje hemeroteke. Hemeroteka se ponovno navodi u "Pravilniku o sistematizaciji radnih mjesta Etnografskog muzeja u Zagrebu" iz 1977. prema kojem se vodi u biblioteci muzeja (Gjetvaj 1989: 56). ${ }^{8}$ Godine 2005. donesen je "Statut Etnografskog muzeja

7 Primarna dokumentacija Etnografskoga muzeja vodi se u računalnom programu za obradu muzejske građe $\mathrm{M}++$. Sekundarna dokumentacija vodi se u relacijskoj bazi S + + . Današnji sustav obrade muzejske građe i dokumentacije u računalnom obliku tercijarnu dokumentaciju vodi kroz nadzor nazivlja koji se postiže primjenom kontroliranih rječnika i tezaurusa, a u svrhu poboljšanja dostupnosti i kvalitetnijega pretraživanja (Vlatković 2019: 70-71).

8 Prema Pravilnicima o sistematizaciji radnih mjesta Etnografskog muzeja iz 1980. i 2002. te Statutu Etnografskog muzeja iz 2000. godine hemeroteka se također vodi u knjižnici Muzeja. Po osnutku Muzeja formirana je priručna knjižnica, a 1920. godine osnovana je kao zasebni odjel Muzeja. Za rad i vođenje muzejske knjižnice bili su zaduženi 
u Zagrebu" prema kojem se hemeroteka vodi u Dokumentaciji (unutar Odjela zbirki i dokumentacije) sukladno važećem "Pravilniku o sadržaju i načinu vođenja muzejske dokumentacije o muzejskoj građi” (NN 108/2002) te je iste godine hemerotečna građa izlučena iz knjižnice.

Vođenje hemerotečne građe Etnografskoga muzeja u Zagrebu započeto je 2017. godine i tada su obrađivani članci pristigli u muzej od siječnja 2017. na dalje. Od 2019. godine započinje obrada i digitalizacija građe prikupljane od osnutka muzeja do 2016. godine te je autorica teksta bila uključena u taj proces. ${ }^{9}$

Prilikom utvrđivanja stanja hemerotečne građe krajem 2018. godine i tijekom 2019. u dokumentaciji Etnografskoga muzeja pronađene su dvije mape s novinskim isječcima ("Berger", "Franić"), 32 registratora te prateći članci izložaba umetnuti u mape ${ }^{10}$. Mapa "Berger" sadrži originalne članke stranoga i domaćega tiska vezane za osnutak i rad Etnografskoga muzeja u Zagrebu te uz život i rad Salamona Bergera, prvoga ravnatelja muzeja (od 1919. do 1930. godine). Mapa "Franić" sastoji se od 29 kartonskih mapa u kojima su zalijepljeni izrezani članci koji su se tematikom uglavnom vezali uz svakodnevnicu života uz poneki članak vezan uz rad Etnografskoga muzeja, a objavljeni su u razdoblju od 1936. do 1939. godine, kada je ravnatelj Etnografskoga muzeja bio Ivo Franić.

U 32 registratora bili su pohranjeni novinski isječci objavljeni u razdoblju od 1945 . do 2016. godine. Članci su bili raspoređeni u registratore po godinama te po sadržaju članaka (muzej, razno). Stariji registratori su sadržavali originalne članke uglavnom etnografske tematike i tematike vezane uz izložbe Etnografskoga muzeja, no devedesetih godina 20. stoljeća, kada se ostvaruje suradnja s Presscutom, ${ }^{11}$ broj prikupljenih članaka se povećao kao i spektar tema. Presscut je prikupljao članke koji su sadržavali ključne riječi: etnologija, etnografija, etnografske izložbe, etnografski muzej. Rezultat toga su bile stotine prikupljenih kopija članaka na mjesečnoj razini koji su se uglavnom doticali rada etnografskih ustanova koje nisu imale direktnu poveznicu s Etnografskim muzejom u Zagrebu. Uz kopije članaka dobivenih posredstvom Presscuta, u registratorima su sačuvani i tiskani primjerci koji su se uglavnom (ali ne isključivo) ticali rada Etnografskoga muzeja. Od 2006. godine članci se pohranjuju na CD-u, no broj dobivenih članaka se nije smanjio sve do kraja 2010. godine od kada se prikupljaju isključivo članci vezani uz Etnografski muzej u Zagrebu i etnografske izložbe. Od 2016. godine hemeroteka se više ne pohranjuje na CD-u već Presscut šalje članke putem maila u PDF obliku te se pohranjuju u bazi za računalnu obradu $\mathrm{S}++$.

djelatnici muzeja različitih struka sve do 1995. godine kada je zaposlena Irena Kolbas kao prva knjižničarka u knjižnici EMZ-a (Kolbas 2019: 75, 82).

9 Krajem 2018. godine započinjem stručno osposobljavanje u Etnografskom muzeju u Zagrebu. Prvi dio stručnoga osposobljavanja odnosio se na sređivanje primarne dokumentacije s mentoricom Aleksandrom Vlatković, a u drugom dijelu autorica teksta je započela obradu i digitalizaciju hemerotečne građe koja je bila prikupljana od osnutka Muzeja.

10 Novinski isječci pronađeni su prilikom revizije izložbi i prateće izdavačke djelatnosti, objavljeni u razdoblju od 1919. do 1995. godine.

11 Tvrtka za medijsko praćenje. 


\section{SREĐIVANJE I DIGITALIZACIJA HEMEROTEČNE GRAĐE}

Kao i veći dio dokumentacijske građe, hemerotečna građa prikupljana je od osnutka Muzeja. Međutim, nije bila obrađivana niti je vođena evidencija. Obrada i vođenje započeto je 2017. godine, a digitalizacija 2019. godine.

Prilikom pripreme za digitalizaciju hemerotečne građe svi prikupljeni članci su pročitani te je rađena selekcija. Za članke koji su objavljeni prije 2002. godine nije se radila značajnija selekcija te su novinski članci bili objedinjeni neovisno o temi te kronološki posloženi. Članci koji su objavljeni od 2002. godine na dalje selektirani su prema kriterijima Pravilnika iz 2002. godine u dogovoru s voditeljicom fonda te su obrađeni oni članci koji su pratili djelatnost muzeja.

Članci objavljeni od osnutka muzeja do devedesetih godina 20. stoljeća vezani su uz etnografske teme te teme koje prate djelatnost muzeja. ${ }^{22}$ Od 1999. godine broj članaka se povećao, a teme su bile raznovrsnije. Izdvojeni su članci koji se bave djelatnošću muzeja te su pripremljeni za digitalizaciju dok su ostali pohranjeni u dvije arhivske kutije. ${ }^{13}$

Građa pripremljena za upis obrađena je u bazi za računalno vođenje dokumentacijskih fondova S + + kroz fond Hemeroteke. Pri upisu u bazu ispunjene su sljedeće kategorije: inventarna oznaka, godina, podzbirka, naslov članka, vrsta članka, autor, publikacija, ISBN/ISSN, izdavač, datum izdanja, podatak o ilustraciji i jeziku i kratki sadržaj (upisivan u napomenu). Ako je to bilo moguće, uspostavila bi se veza u bazi s drugim dokumentacijskim fondovima poput izložbi. Zapisima su pridružene digitalne preslike. ${ }^{14}$ Novinski članci skenirani su pomoću skenera MICROTEK MRS-3200A3 u TIFF formatu te obrađeni programom Vuescan u rezoluciji $400 \mathrm{dpi} .{ }^{15}$ Skenirani članci i oni dostavljeni u PDF formatu (putem maila ili CD-a) pohranjeni su na eksternom disku i na serveru. Digitalnim preslikama dodijeljena je odgovarajuća inventarna oznaka.

Prilikom revizije Fonda izložbi 2019. godine pronađeni su članci vezani uz same izložbe te su izlučeni u fond Hemeroteke. Naslovi članaka su bili pretraživani u bazi podataka te ako je ustanovljeno da je pretraživani članak duplikat, pridružena mu je već postojeća inventarna oznaka te se članak pohranio uz već inventarizirani članak. ${ }^{16}$ Članci koji nisu bili duplikati, inventarizirani su, upisani u bazu te skenirani i pohranjeni na isti način kao članci prije.

Kao što je već navedeno, pronađeno je više istih primjeraka članaka. Originali su dobili istu inventarnu oznaku i zajedno su pohranjeni u dokumentaciji. U slučaju postojanja originala i kopije novinskoga članka, kopije su bile eliminirane. U slučaju kada su bili

12 Dio novinskih isječaka koji se nalaze u mapi "Franić" ne odnose se na etnologiju i rad Muzeja te oni nisu uključeni $\mathrm{u}$ inventarizaciju što je naznačeno napomenom na mapi.

13 Na arhivskim kutijama je napisano "Neevidentirano 1971 - 2002" i "Neevidentirano 2003 - 2016".

14 Za potrebe pridruživanja fotografija u bazi, digitalne preslike su smanjene i prebačene u JPG format dok su one u PDF obliku ostale u originalu te je u planu i za njih napraviti JPG.

15 Članci koji su bili preveliki da bi mogli biti skenirani označeni su i pripremljeni za fotografiranje. Načinjene fotografije bit će spojene s upisom u bazu.

16 U bazi bih naznačila postojanje više primjeraka članka pod kategoriju napomena. 
pronađeni originalni novinski članak i PDF verzija dobivena na CD-u ili putem maila, original je bio pohranjen $\mathrm{u}$ dokumentaciju, dok je članak u PDF obliku pohranjen na eksternom disku i na serveru te pridružen uz odgovarajući zapis u bazi. Kopije su također bile eliminirane. Nakon inventarizacije i obrade građe, novinski članci preventivno su zaštićeni te su pohranjeni kronološki s oznakom smještaja u dokumentaciji muzeja. ${ }^{17}$

U navedenom procesu digitalizacije hemerotečne građe ostvareno je 3529 zapisa u bazi S+ + te 2892 digitalnih preslika. U planu rada Dokumentacije je sadržajna obrada svih članaka kako bi bili pretraživi i dostupni korisnicima.

\section{ANALIZA DIGITALIZIRANE HEMEROTEČNE GRAĐE}

Na samom početku rada Etnografskoga muzeja u Zagrebu prikupljani su članci usko vezani uz osnutak i rad muzeja te život i rad Salamona Bergera. Pohranjeno je i nekoliko članaka koji su se odnosili na Bergerovu izložbu kućne industrije koja je bila postavljena prije osnutka muzeja.

Tridesetih godina 20. stoljeća zabilježen je porast prikupljenih članaka. Od 509 digitaliziranih članaka, 395 se odnosilo na članke iz mape "Franić" koji su se bavili temama iz svakodnevnoga života dok se ostalih 114 zapisa odnosilo na komunikaciju između Ive Franića i Milovana Gavazzija, raznovrsne etnografske teme i sprovod S. Bergera. U tom periodu nisu prikupljani članci vezani uz izložbe Etnografskoga muzeja. ${ }^{18}$

Od 1940. do kraja 1969. godine prikupljaju se članci uglavnom vezani uz izložbe Etnografskoga muzeja.

Sedamdesetih godina 20. stoljeća ponovno je zabilježen porast prikupljenih članaka. Skupljaju se članci vezani uz izložbe te uz otvorenje obnovljenoga muzeja i novoga stalnog postava. Prikupljaju se i članci raznih etnografskih tema. Osamdesetih se nastavilo s praksom skupljanja članaka koji su se uglavnom ticali rada muzeja. Od devedesetih nadalje dolazi do već spomenutoga rasta prikupljenih članaka posredstvom Presscuta. Iako su se skupljali članci širokoga spektra tema, digitalizirani su bili članci koji su se isključivo ticali rada muzeja i njegovih djelatnika.

Tijekom prikupljanja hemerotečne građe u periodu od 1919. do 2016. godine skupljali su se članci domaćega i stranoga tiska, a oni iz stranoga tiska bili su uglavnom originali članaka vezanih uz izložbe Etnografskoga muzeja (gostovanja).

Iz analize može se zaključiti kako je postojala praksa skupljanja hemerotečne građe raznih etnografskih tema, no isto tako je primjetan i kontinuitet skupljanja te svijest o važnosti dokumentiranja djelatnosti Muzeja od njegova osnutka. Članci koji su digitalizirani uglavnom su bili osvrti (1217) i najave (669) za izložbe Etnografskoga muzeja. Najzastupljenije novine u kojima su bili objavljeni digitalizirani članci su bile Večernji list (560) te Vjesnik (431).

17 Građa je očišćena i pohranjena u beskiselinske mape.

18 Prilikom revizije Fonda izložbi utvrđeno je kako nisu prikupljani sitni tisak ni plakati vezani uz izložbe održane tridesetih godina 20. stoljeća. 
Graf 1. Članci koji su inventarizirani, a datacija nije utvrđena nisu ubrojeni u statistiku.

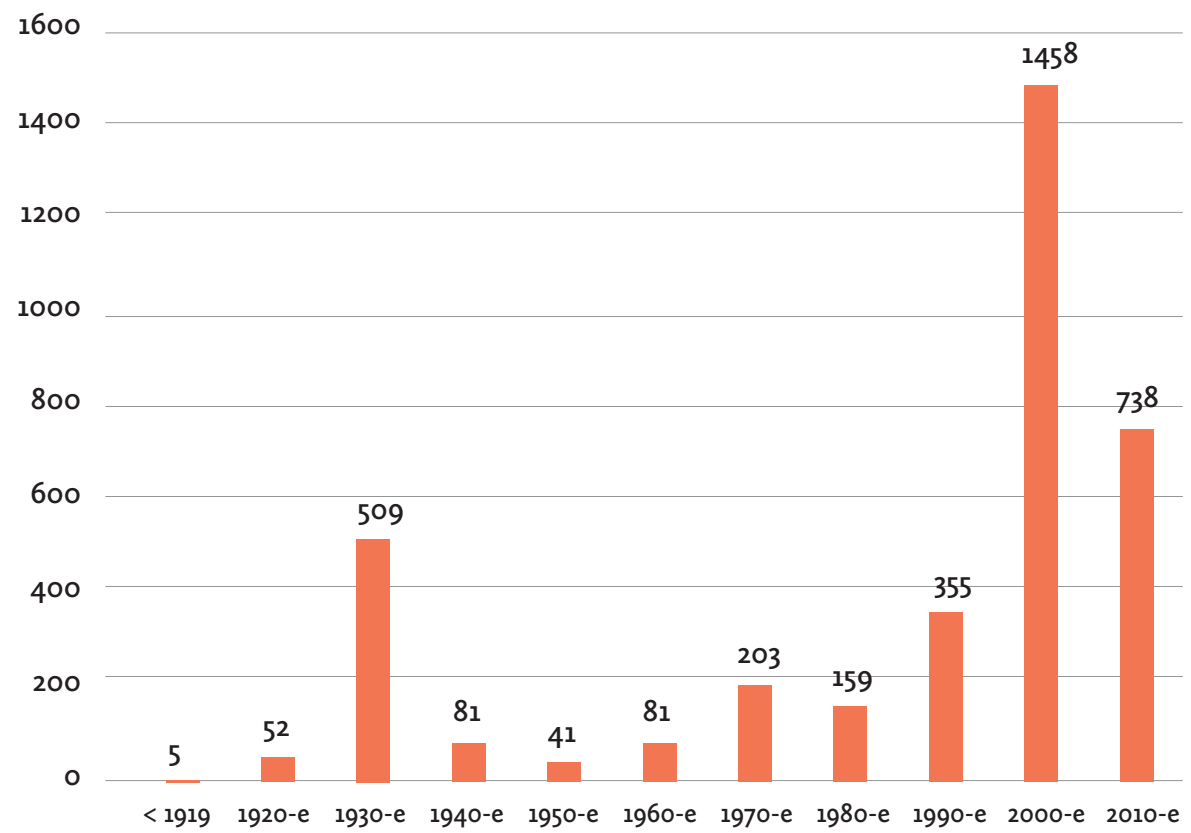

\section{ZAKLJUČAK}

Kroz sto godina djelovanja Etnografskoga muzeja u Zagrebu, važnost, opseg i položaj dokumentacije se mijenjao. Od samoga početka djelovanja Muzeja vodila se dokumentacija o muzejskoj i dokumentacijskoj (audiovizualnoj) građi. ${ }^{19}$ Kako prije "Pravilnika o sadržaju i načinu vođenja muzejske dokumentacije o muzejskoj građi”, koji je donesen 2002. godine, nije postojalo pravilo kako pristupiti hemeroteci i na koji način prikupljati takvu građu, muzeji su imali slobodu sami oblikovati svoje fondove hemeroteke. Tako se i u Etnografskom muzeju u Zagrebu, koji od svog osnutka prikuplja hemerotečnu građu, kroz godine mijenjala svijest o tome što i kako prikupljati te su se skupljali članci različitih tema (etnografske, muzeološke ali i brojne druge), a građa se selila iz dokumentacije u knjižnicu i obratno.

Analizom politike prikupljanja hemerotečne građe od osnutka Muzeja do danas možemo zaključiti kako se od samoga početka vodila briga o prikupljanju članaka o radu Muzeja i njegovim djelatnicima. Iako se nije provodila selekcija i obrada prikupljene hemerotečne građe, možemo uočiti da je postojala svijest od osnutka o važnosti bilježenja informacija o radu Muzeja te da je fokus uglavnom bio na člancima vezanih uz izložbe Etnografskoga muzeja. 
Digitalizacijom, nastavkom prikupljanja hemerotečne građe i daljnjim planovima sadržajne obrade svih članaka (tema, osobe, zemljopisne i vremenske odrednice) omogućit će se pretraživost i dostupnost informacija o radu Muzeja korisnicima.

Fond Hemeroteke sadrži važnu dokumentacijsku građu koja nam pruža razne informacije o djelatnosti Etnografskoga muzeja i njezinih djelatnika te ju možemo koristiti u svrhu istraživanja, izložbi te revizije ostalih muzejskih fondova.

\section{LITERATURA I IZVORI:}

GJETVAJ, Nada. 1989. “Etnografski muzej u Zagrebu - u povodu 70. obljetnice”. Etnološka istraživanja 5: 1-144.

KOLBAS, Irena. 2019. "Knjižnica Etnografskoga muzeja u Zagrebu” Etnološka istraživanja 24: 75-84.

MAROEVIĆ, Ivo. 1993. Uvod u muzeologiju. Zagreb: Zavod za informacijske studije Odsjeka za informacijske znanosti, Filozofski fakultet Sveučilišta u Zagrebu.

MAROEVIĆ, Ivo. 2000. "Informacije i dokumentacija u muzejima”. Informatica museologica 31/ 1-2: 13-15.

Pravila Etnografskog muzeja, 1961., Dokumentacija EMZ.

Pravilnik o sadržaju i načinu vođenja muzejske dokumentacije o muzejskoj građi (NN 108/2002)

Pravilnik o sistematizaciji radnih mjesta Etnografskog muzeja u Zagrebu, 1977., Dokumentacija EMZ.

Pravilnik o sistematizaciji radnih mjesta Etnografskog muzeja u Zagrebu, 1980., Dokumentacija EMZ.

Pravilnik o sistematizaciji radnih mjesta Etnografskog muzeja u Zagrebu, 2002., Dokumentacija EMZ.

Statut Etnografskog muzeja u Zagrebu, 1966., Dokumentacija EMZ.

Statut Etnografskog muzeja u Zagrebu, 1970., Dokumentacija EMZ.

Statut Etnografskog muzeja u Zagrebu, 1971., Dokumentacija EMZ.

Statut Etnografskog muzeja u Zagrebu, 2000., Dokumentacija EMZ.

Statut Etnografskog muzeja u Zagrebu, 2005., Dokumentacija EMZ.

TKALČIĆ, Vladimir. 1930. “Etnografski muzej u Zagrebu 1919 - 1929”. Narodna starina 9: 132-148.

VINAJ, Marina. 1998. "Hemeroteka Muzeja Slavonije”. Informatica museologica 29/1-2: 62-68.

VLATKOVIĆ, Aleksandra. 2019. “Dokumentacija Etnografskog muzeja u Zagrebu”. Etnološka istraživanja 24: 61-74.

Zakon o muzejima (NN 61/2018).

http://www.emz.hr/O\%20muzeju/Povijest\%20muzeja (pristup 14.2.2020.).

https://www.enciklopedija.hr/Natuknica.aspx?ID =24926 (pristup 14.2.2020.). 